\title{
Caregiver and the Process of Caring for Older Adults
}

Bruna Mourão Moura ${ }^{1}$, Hisllaeny Almeida Sousa ${ }^{2}$, Emily Quintana Xavier de Araujo ${ }^{1}$, Tábatta Renata Pereira de Brito ${ }^{3}$, Daniella Pires Nunes ${ }^{1,2}$

${ }^{1}$ Master Program in Science and Health Education, Federal University of Tocantins, Palmas (TO), Brazil

${ }^{2}$ Nursing Course, Federal University of Tocantins, Palmas (TO), Brazil

${ }^{3}$ Faculty of Nutrition, Federal University of Alfenas, Alfenas (MG), Brazil

Corresponding author: Daniella Pires Nunes, Federal University of Tocantins, Palmas (TO), Brazil. Tel: 55-63- 3229- 4213; E-mail: dpiresnunes@yahoo.com.br

Received: Apr 26, 2018; Accepted: Apr 27, 2018; Published: Apr 30, 2018

Copyright: ( 2018 Moura BM, et al. This is an open-access article distributed under the terms of the Creative Commons Attribution License, which permits unrestricted use, distribution, and reproduction in any medium, provided the original author and source are credited.

\section{Editorial}

Population aging has occurring at a fast pace due to demographic and epidemiological changes. In this scenario, it is highlighted the increase in noncommunicable and chronic diseases that may predispose the individual to physical debility, which often compromise the autonomy and independence of the older adults [1-3].

When the older adults have any compromising to perform the basic activities of daily living (ADL) or instrumental activities of daily living (IADL) one may need the help of a caregiver. The caregiver is the person, family member or not, who cares for the elderly person who needs assistance [4].

The caregiver's demand will depend on the compromised daily tasks and the necessary frequency to manage them. Therefore, authors have proposed classification of care need that reflects the necessity of a caregiver (for example, sporadic, intermittent or full-time) [5].

Public policies indicate that the act of caring for the elderly is a shared responsibility between family, society and public power to insure a better quality of life for this individual. In Brazil, older adults care is provided, in particular, by the family. Pinquart and Sorensen (2011) evaluated 168 studies and pointed out that the majority of caregivers are relatives, female and in the process of aging [6].

The act of caring is invaluable. The bond between the elderly and the caregiver transcends the roles of family function. The caregivers usually recognize the positive aspects of their duties early in the process, feeling good about fulfilling tasks that would be expected from them at some point of their life. For example, when daughters care for their mothers, the act of caring would be seen as an exchange of roles, where the person who used to care also needs care [7]. This process is quite complex. It involves positive aspects related to the execution of the caring role and sometimes can generate negative repercussions, so it is necessary to observe the factors that contribute to this. Accordingly, it is essential to identify the need for caregiver support services, so they can see the importance of their role and receive support and guidance that turn caring a light and beneficial practice for both of them.

When providing care, the need of the older adults is put first, and in some cases the caregivers forget to look at themselves. Constant care requires that the caregivers make changes in their daily lives, which in turn can lead to physical, emotional or social overload. It should be stressed that it is common for people to become caregivers since there is no other option, taking responsibilities and activities without training, which creates a number of stressful situations [8].

Several emotions may be present when there is exclusive dedication to the care of others. It is essential for health professionals to identify the signs of the caregiver's overload in order to avoid that these issues interfere in their quality of life, as well as negatively affect the elderly cared [9].

The family caregiver, for the most part, is not seen as someone who deserves attention and guidance. The elderly are often the focus of the care process and the caregiver goes unnoticed. Health professionals, however, have the role of inserting the caregiver in this process. Such professionals should schedule interventions that minimize the impact of the dependency condition of the older adults on the caregiver, as well as promote an active aging through health promotion and harm prevention with a direct impact on the caring process performed by the caregiver [10].

An alternative would be the encouragement to the implementation of caregivers' support networks, since caregivers who refer available social support have lower care overload scores [11]. The participation of health professionals in the caregiver-older adults cared relationship makes evident improved health quality of both through the relief of tension. When considering the particularities on the caregiver and the older adults cared, the professional's intervention strengthens the capacity to cope with stress, crises and other difficulties that are part of the caregiver's reality [12].

Therefore, it is necessary to strengthen this professional-older adults-caregiver bond, in order to prevent overload, stress, wear off and even decrease the connection between peers as a consequence of the negative aspects created, contributing in a significant way in the recognition of values and care's better quality.

\section{References}

1. Loureiro LSN, Pereira MA, Fernandes MGM, Oliveira JS (2015) Percepção de enfermeiras sobre a tensão do papel de cuidador. Rev. Baiana de Enferm 29: 164-171.

2. Rocha MPF, Vieira MA, Sena RR (2008) Desvelando o cotidiano dos cuidadores informais de idosos. Rev Bras Enferm 61: 801-808.

3. Aguiar ESS, Gomes IP, Fernandes MGM, Silva AO (2011) Representações sociais do cuidar de idosos para cuidadores: revisão integrativa. Rev Enferm UERJ 19: 485-490.

4. Brasil (2012) Caderno de Atenção Domiciliar. Ministério da Saúde. Secretaria de Atenção à Saúde. Departamento de Atenção Básica 1: 101.

5. Nunes DP, Brito TRP, Corona LP, Alexandre TS, Duarte YAO (2018) Idoso e demanda de cuidador: proposta de classificação da necessidade de cuidado. Rev Bras Enferm 7

6. Pinquart M, Sorensen S (2011) Spouses, adult children, and children-inlaw as caregivers of older adults: A meta-analytic comparison. Psychol. Aging 26: 1-14.

7. Mafra SCT (2011) A tarefa do cuidar e as expectativas sociais diante de um envelhecimento demográfico: a importância de ressignificar o papel da família. Rev Bras Geriatr Gerontol 14: 353-363. 
Citation: Moura BM, Nunes DP, de Araujo EQX, Sousa HA, de Brito TRP (2018) Caregiver and the Process of Caring for Older Adults. J Gerontol Geriatr Res 7: e150. doi:10.4172/2167-7182.1000e150

Page 2 of 2

8. Floriano LA, Azevedo RCS, Reiners AAO, Sudré MRS (2012) Cuidado realizado pelo cuidador familiar ao idoso dependente, em domicílio, no contexto da estratégia de saúde da família. Texto Contexto Enferm 21: 543-548.

9. Conceição IRS (2014) Enfermagem gerontológica e suas intervenções nas grandes síndromes geriátricas. Universidade Federal do Maranhão. UNASUS/UFMA 2: 8-30

10. Rocha FCV, Santos WCL, Lima VF, Moura MEB, Sousa CMM, et al. (2011) Cuidador familiar: dificuldades para cuidar do idoso no domicílio. R pesq cuid fundam Online 3: 18-27.
11. Del-Pino-Casado R, Frías-Osuma A, Palomino-Moral PA, RuzafaMartínez M, Ramos-Morcillo AJ (2018) Social support and subjective burden in caregivers of adults and older adults: A meta-analysis. PLoS ONE 13: e0189874.

12. Emiliano MS, Lindolpho MC, Valente GSC, Chrizóstimo MM, Sa SPC, et al. (2017) A percepção da consulta de enfermagem por idosos e seus cuidadores. Rev enferm UFPE online 11: 1791-1797. 